$\mathrm{Y}-12$

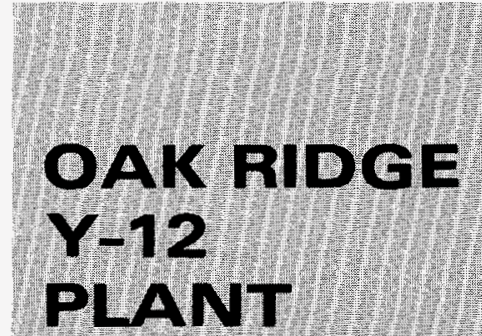

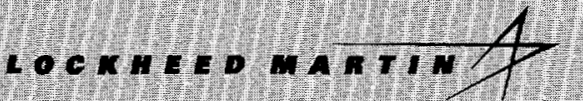
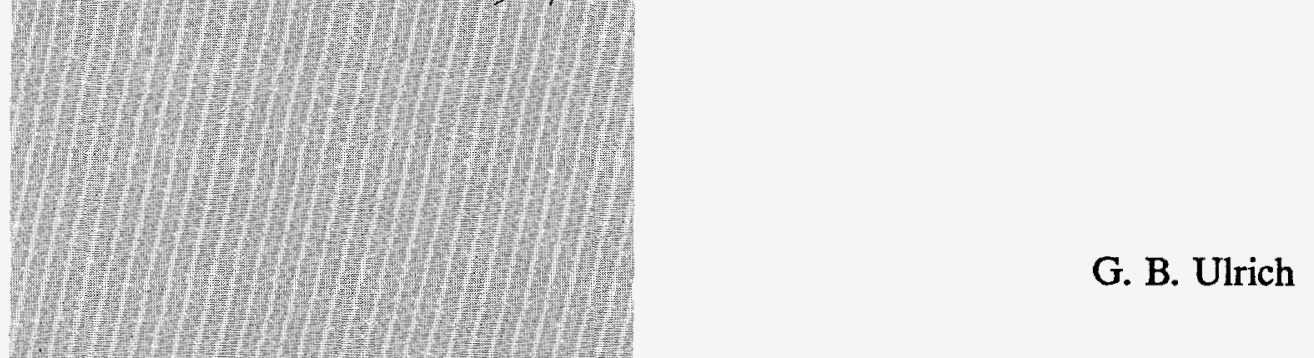

1)

\%
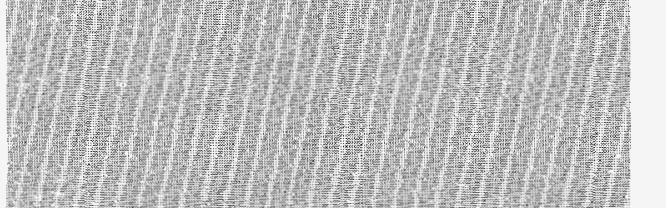

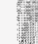

(1)

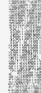

\section{站}

(1)

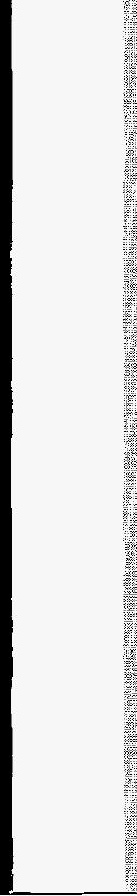

September 1996

MANAGED BY

LOCKHEED MARTINENERGY SYSTEMS, INC. FOR THE UNITED STATES DEPARTMENT OF ENERGY

\section{THE EFFECTS OF VENT-NOTCH AREA ON BULGING AND THINNING DURING THE CLAD VENT SET CLOSURE-WELD OPERATION}

$$
\begin{gathered}
\text { DEC } 20 \text { HOS } \\
\text { OSTI }
\end{gathered}
$$




\section{DISCLAIMER}

This report was prepared as an account of work sponsored by an agency of the United States Government. Neither the United States Government nor any agency thereof, nor any of their employees, makes any warranty, express or implied, or assumes any legal liability or responsibility for the accuracy, completeness, or usefulness of any information, apparatus, product, or process disclosed, or represents that its use would not infringe privately owned rights. Reference herein to any specific commercial product, process, or service by trade name, trademark, manufacturer, or otherwise, does not necessarily constitute or imply its endorsement, recommendation, or favoring by the United States Government or any agency thereof. The views and opinions of authors expressed herein do not necessarily state or reflect those of the United States Government or any agency thereof. 


\title{
THE EFFECTS OF VENT-NOTCH AREA ON BULGING AND THINNING DURING THE CLAD VENT SET CLOSURE-WELD OPERATION
}

\author{
G. B. Ulrich \\ Development Division
}

September 1996

Prepared by the

Oak Ridge Y-12 Plant

P. O. Box 2009, Oak Ridge, Tennessee 37831-8169

managed by

LOCKHEED MARTIN ENERGY SYSTEMS, INC.

for the

U. S. DEPARTMENT OF ENERGY

under contract DE-AC05-84OR21400 


\section{DISCLAIMER}

Portions of this document may be illegible in electronic image products. Images are produced from the best available original document. 


\section{CONTENTS}

LIST OF FIGURES $\ldots \ldots \ldots \ldots \ldots \ldots \ldots \ldots \ldots \ldots \ldots \ldots$

SUMMARY $\ldots \ldots \ldots \ldots \ldots \ldots \ldots \ldots \ldots \ldots \ldots \ldots \ldots \ldots \ldots \ldots \ldots \ldots$

INTRODUCTION $\ldots \ldots \ldots \ldots \ldots \ldots \ldots \ldots \ldots \ldots \ldots \ldots \ldots \ldots$

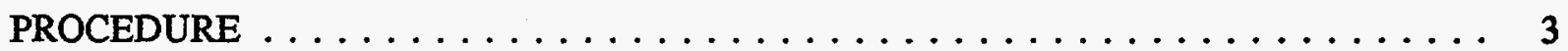

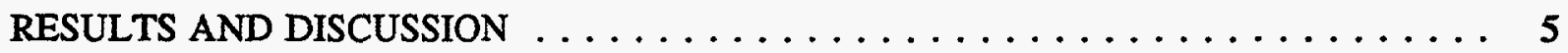

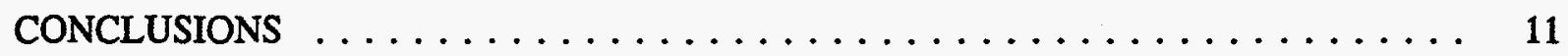

FUTURE WORK $\ldots \ldots \ldots \ldots \ldots \ldots \ldots \ldots \ldots \ldots \ldots \ldots \ldots \ldots \ldots$

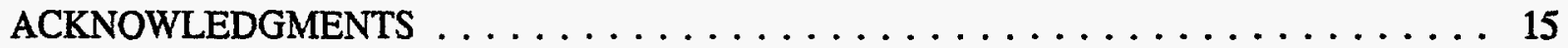

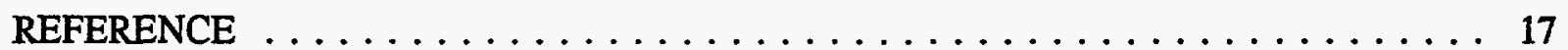





\section{FIGURES}

Figure

Page

Typical roundness scan on the CVS outer contour at the weld centerline showing weld direction and location of vent notches and bulge region $\ldots \ldots \ldots \ldots \ldots$

Maximum outside diameter versus minimum wall thickness at weld centerline $\ldots \ldots \ldots \ldots \ldots \ldots$

Total vent-notch area versus minimum wall thickness at weld centerline . . . . . . . . . . 8 



\section{SUMMARY}

Twelve simulant-fueled clad vent sets (CVSs) with vent-notch areas ranging from $0.086 \mathrm{~mm}^{2}$ to $0.256 \mathrm{~mm}^{2}$ were welded to evaluate the effects of vent-notch area on bulging and thinning at the weld centerline. The evaluation showed that

1. the greater the bulge, the thinner the wall thickness in the bulge region; and

2. the least bulging/thinning occurred with notch areas from $0.147 \mathrm{~mm}^{2}$ (corresponds approximately to the typical area for one standard notch mated to one wide notch) to $0.210 \mathrm{~mm}^{2}$ (corresponds to a vent-notch area slightly above the maximum area permitted for one standard notch mated with one wide notch).

Based on these results, CVSs with vent-notch areas up to $0.210 \mathrm{~mm}^{2}$ are acceptable for flightquality use. The design requirements were modified to allow the use of shield cups with wider vent notches $-0.45 / 0.60 \mathrm{~mm}$ wide versus the standard width of $0.25 / 0.35 \mathrm{~mm}$. Subsequent production data from Los Alamos National Laboratory shows a marked reduction in bulges/blowouts for CVS units welded with shield cups having wider vent notches versus those welded with standard vent notches.

It is recommended, for ease of manufacture in post-Cassini missions, that the vent-notch dimensional requirements be modified slightly so that they are the same for the vent and shield cups: $0.20 / 0.25 \mathrm{~mm}$ deep by $0.30 / 0.40 \mathrm{~mm}$ wide. CVSs with vent notches in this size range are expected to maintain or exceed the already improved bulge/blowout yield during the closure-weld operation. However, these recommended vent-notch dimensions should be evaluated before changing the design requirements. Additionally, it is recommended that the weld-taper parameters be evaluated for their effects on bulging/thinning. 

INTRODUCTION

The internal gas pressure during clad vent set (CVS) welding is vented through aligned vent notches in each cup. For Galileo, Ulysses, and most of Cassini CVS production, the vent-notch dimensional requirements for both cups were as follows:

1. vent-notch depth, $0.15 / 0.20 \mathrm{~mm}$;

2. vent-notch width, $0.25 / 0.35 \mathrm{~mm}$;

3. bottom of vent-notch corners, sharp to full radius;

4. top of vent-notch edge, $0.05 \mathrm{~mm}$ maximum break; and

5. maximum variation between vent notch and grit-blasted triangle centerlines, $3^{\circ}$.

The vent notches were ground using a $127-\mathrm{mm}$-diam, metal-bonded diamond (100 grit and 100 concentration) wheel approximately $0.25 \mathrm{~mm}$ thick. The wheel was advanced into the iridium cup at a rate of $0.0127 \mathrm{~mm} / \mathrm{pass}$. The dimensional features were inspected using an optical comparator.

During the fuel encapsulation operation (with ${ }^{238} \mathrm{PuO}_{2}$ fuel pellets) at Los Alamos National Laboratory (LANL), excessive bulges or blowouts at the CVS closure-weld tie-in location occurred with $11.8 \%$ (27 out of 229) of the flight-quality welds made with the aforementioned standard ventnotch dimensions. These bulges and blowouts are primarily the result of inadequate venting of the increased gas pressure during the thermal cycle of the closure-weld operation. Proper venting is dependent mostly upon the weld parameters and the total vent-notch area.

In February 1995, the welding current used at LANL was increased to a peak of $116 \mathrm{~A}$ to smooth the transition between cup sections of different thickness and to produce weld-shield fusions clearly identifiable by ultrasonic B-scan evaluations. Before this time, the peak weld current ranged from 111 to $116 \mathrm{~A}$, depending on the particular weld campaign. The early bulge/blowout losses were 9.4\% versus $14.5 \%$ for most of 1995 when the peak welding current was consistently $116 \mathrm{~A}$. The increase in peak current reduced the number of ultrasonic evaluation rejects and thus improved the overall closure-weld yield, but it also increased the incidence of bulges/blowouts.

Because of the increased incidence of bulges/blowouts in the ${ }^{238} \mathrm{PuO}_{2}$-fueled CVS units, LANL personnel requested that consideration be given to increasing the vent-notch size to minimize further the loss of CVS hardware and the potential loss of ${ }^{238} \mathrm{PuO}_{2}$ pellets. Thus, increasing further the production yield of the closure-weld operation would avoid potentially severe schedule delays. ${ }^{1}$

At the time of the request (July/August 1995) to increase the vent-notch size, most of the flight-quality CVS units for the Cassini mission were complete but not yet fueled. Handling and cleanliness concerns associated with the frit vent assembly and the decontamination cover portions of vent cup assemblies during potential vent-notch reworking operations dictated that only shield cups be considered for vent-notch size increases on completed CVS units. Thus, it was decided to return only the shield cups for widening of the vent notches if a vent notch/welding study showed that increasing the vent-notch width would be beneficial. 

An evaluation of the effects of four vent-notch area regimes $(0.090,0.150,0.190$, and $0.240 \mathrm{~mm}^{2}$ ) was conducted to determine the vent-notch area limits for flight-quality clad vent sets (CVSs). The $0.090-\mathrm{mm}^{2}$ regime represents the typical vent-notch area of CVSs with two standard vent notches. The $0.150-\mathrm{mm}^{2}$ regime represents the typical vent-notch area of CVSs with one wide (drawing requirement is for same depth as standard notch by $0.45 / 0.60 \mathrm{~mm}$ wide) and one standard vent notch. The $0.190-\mathrm{mm}^{2}$ regime is for the maximum permissible vent-notch area of CVSs with one wide and one standard vent notch. The $0.240-\mathrm{mm}^{2}$ regime represents the maximum vent-notch area of CVSs with two wide notches.

Vent notches with various depths and widths were ground in 24 cups so that three CVSs were at each of the four vent-notch area regimes. Both the notches and the cup weld-zone attributes (diameter, roundness, flatness, and wall thickness) were dimensionally inspected. The 12 matched CVS units were welded over outgassed alumina simulant pellets at the Oak Ridge National Laboratory using a duplicate of the gas tungsten arc welding system and procedure used for production at Los Alamos National Laboratory (LANL). ${ }^{3}$ J. F. King and E. A. Franco-Ferreira guided the welding.

After being welded, the simulant-fueled CVSs were first ultrasonically inspected and then dimensionally inspected for roundness and diameter on the outer contour (OC) at the weld centerline. Roundness scans of the OC were acquired to show the extent and location of bulging. Next, each CVS was ground open just below the cup radius of the vent-cup assembly (or pseudo vent-cup assembly, i.e., the top shield cup). The weld shield and the simulant pellet were removed, and the welds were visually examined. Finally, the weld centerline minimum thicknesses were measured using a thread micrometer, and the diameters were remeasured. Also, the wall thicknesses of three CVSs were measured $2 \mathrm{~mm}$ above and below the weld centerline.

After the initial promising results from the first three units in this study, the decision was made to produce $10 \mathrm{CVSs}$ with shield-cup-vent-notch widths from 0.45 to $0.60 \mathrm{~mm}$ and send them to LANL for welding over production ${ }^{238} \mathrm{PuO}_{2}$ pellets. All 10 of these units welded normally and passed through the go/no go ring gauge $(30.226 \mathrm{~mm}$ diam). Next, the rest of the study was completed, and then the CVS flight-quality design requirements were modified to permit shield-cupvent-notch widths to range from 0.45 to $0.60 \mathrm{~mm}$.

Sixty shield cups with standard notches were sent from LANL to the Oak Ridge Y-12 Plant to widen the existing notches. After the vent notches were widened and the cups were recertified, they were returned to LANL for flight-quality production use. Also, the final Cassini production shipment from the Oak Ridge Y-12 Plant in April 1996 included an additional 19 CVSs with shield cups that had virgin wide notches. Thus, LANL received a total of 89 flight-quality CVS units containing shield cups with wide vent notches. Seventy four of these units have been welded and evaluated. The bulge/blowout data for CVS units with wide vent notches have been analyzed and compared with those for units with standard vent notches. 



\section{RESULTS AND DISCUSSION}

Figure 1 is an example of a typical roundness scan on the $O C$ at the weld centerline superimposed on a calculated best fit diameter (dashed circle). Bulging or a convex appearance on the exterior or front surface of the CVS weld coincides with a depression or concave appearance on the interior or back surface. Typically, this altered weld-bead geometry extends from $-15^{\circ}$ to $+40^{\circ}$ (referenced from the vent notches). The minimum wall thickness is found within this region, usually $20^{\circ}$ to $30^{\circ}$ past the vent notches. Note that outside the altered weld-bead region, the wall thickness at the weld centerline is significantly thicker than the cups themselves, whereas the wall thickness is unaltered $2 \mathrm{~mm}$ above and below the weld centerline.

9753-00-1814 center of weld diameter 30.174

MEASUREMENT MODE:

ROUNDNESS

Tue Apr 09 09:02:53 1996

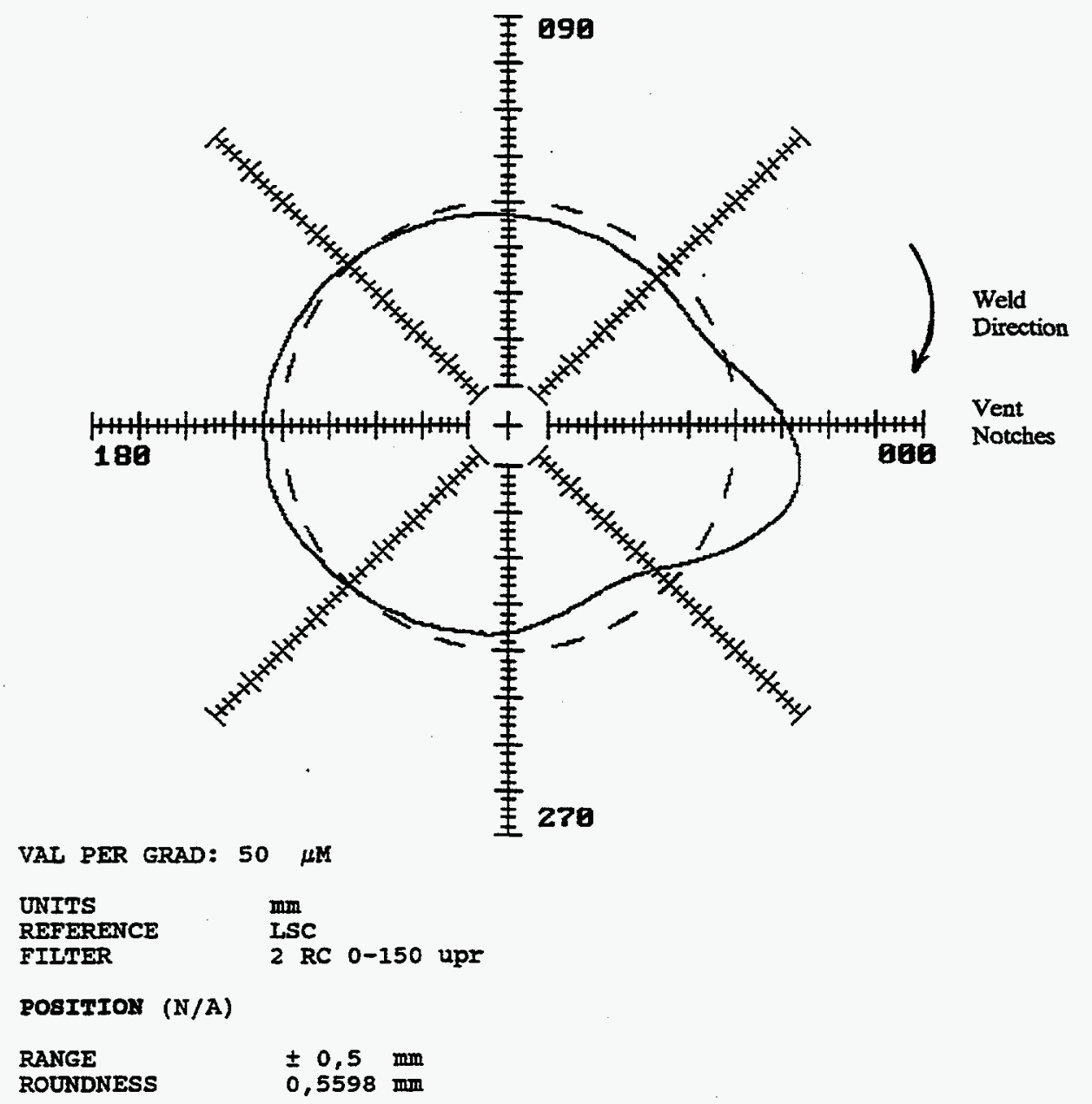

Fig. 1. Typical roundness scan on the CVS outer contour at the weld centerline showing weld direction and location of vent notches and bulge region. 
Two simulant-fueled CVSs failed the ultrasonic inspection; they were also the only units that exceeded the LANL go/no go diameter requirement of $30.226 \mathrm{~mm}$. Additionally, one of the CVSs with the largest vent-notch area was inadvertently welded without the thrust washer on top of the vent-cup assembly. The data from this unit could not be used because of extensive weld-shield fusion at the vent notch, which precluded meaningful weld centerline wall-thickness measurements. Also, the amount of bulging with this unit was significantly less than with the other two units in the same vent-notch area regime. Most likely, the additional material from the weld shield limited the amount of bulging.

The inspection data are summarized in Table 1. Graphic presentation (Fig. 2) of the data for the maximum outside diameter at the weld centerline versus the minimum wall thickness at the weld centerline shows for all 11 CVSs that the greater the bulge the thinner the minimum wall thickness. These data have a correlation coefficient ( $r$ value) of -0.90 . The regression equation predicts that CVSs with diameters at the LANL go/no-go diameter of $30.226 \mathrm{~mm}$ would have a minimum wall thickness at the weld centerline of approximately $0.52 \mathrm{~mm}$. Coincidentally, this measurement is not too far below the formed cup minimum wall thickness requirement (outside the closure-weld zone) of $0.55 \mathrm{~mm}$.

Table 1. Summary of CVS weld zone dimensional data by total vent-notch area

\begin{tabular}{|c|c|c|c|c|}
\hline $\begin{array}{c}\text { Total } \\
\text { vent-notch } \\
\text { area } \\
\left(\mathbf{m m}^{2}\right)\end{array}$ & $\begin{array}{l}\text { Wall } \\
\text { thickness } \\
\text { near } \\
\text { vent notch } \\
\text { before } \\
\text { welding } \\
\text { (mm) }\end{array}$ & $\begin{array}{l}\text { Minimum } \\
\text { wall } \\
\text { thickness } \\
\text { at weld } \\
\text { centerline } \\
\text { (mm) }\end{array}$ & $\begin{array}{c}\text { Reduction } \\
\text { between wall } \\
\text { thickness near } \\
\text { vent notches } \\
\text { before welding } \\
\text { and minimum } \\
\text { wall thickness at } \\
\text { weld centerline } \\
\text { (mm) }\end{array}$ & $\begin{array}{l}\text { Maximum } \\
\text { outside } \\
\text { diameter } \\
\text { at weld } \\
\text { centerline } \\
\text { (mm) }\end{array}$ \\
\hline 0.088 & $0.63 / 0.64$ & 0.528 & 0.107 & 30.174 \\
\hline $0.086^{a}$ & $0.66 / 0.67$ & 0.503 & 0.162 & 30.293 \\
\hline 0.091 & $0.66 / 0.67$ & 0.550 & 0.115 & 30.090 \\
\hline 0.147 & $0.67 / 0.68$ & 0.610 & 0.065 & 29.912 \\
\hline 0.154 & $0.64 / 0.68$ & 0.604 & 0.056 & 30.035 \\
\hline 0.150 & $0.65 / 0.66$ & 0.590 & 0.065 & 30.020 \\
\hline 0.189 & $0.64 / 0.67$ & 0.604 & 0.051 & 30.037 \\
\hline 0.191 & $0.65 / 0.65$ & 0.653 & -0 & 29.983 \\
\hline 0.210 & $0.62 / 0.65$ & 0.655 & -0 & 30.002 \\
\hline 0.256 & $0.64 / 0.69$ & 0.587 & 0.078 & 30.077 \\
\hline $0.254^{a}$ & $0.63 / 0.67$ & 0.472 & 0.178 & 30.277 \\
\hline
\end{tabular}

a Ultrasonic inspection and go/no go diameter (30.226 $\mathrm{mm}$ max) reject 


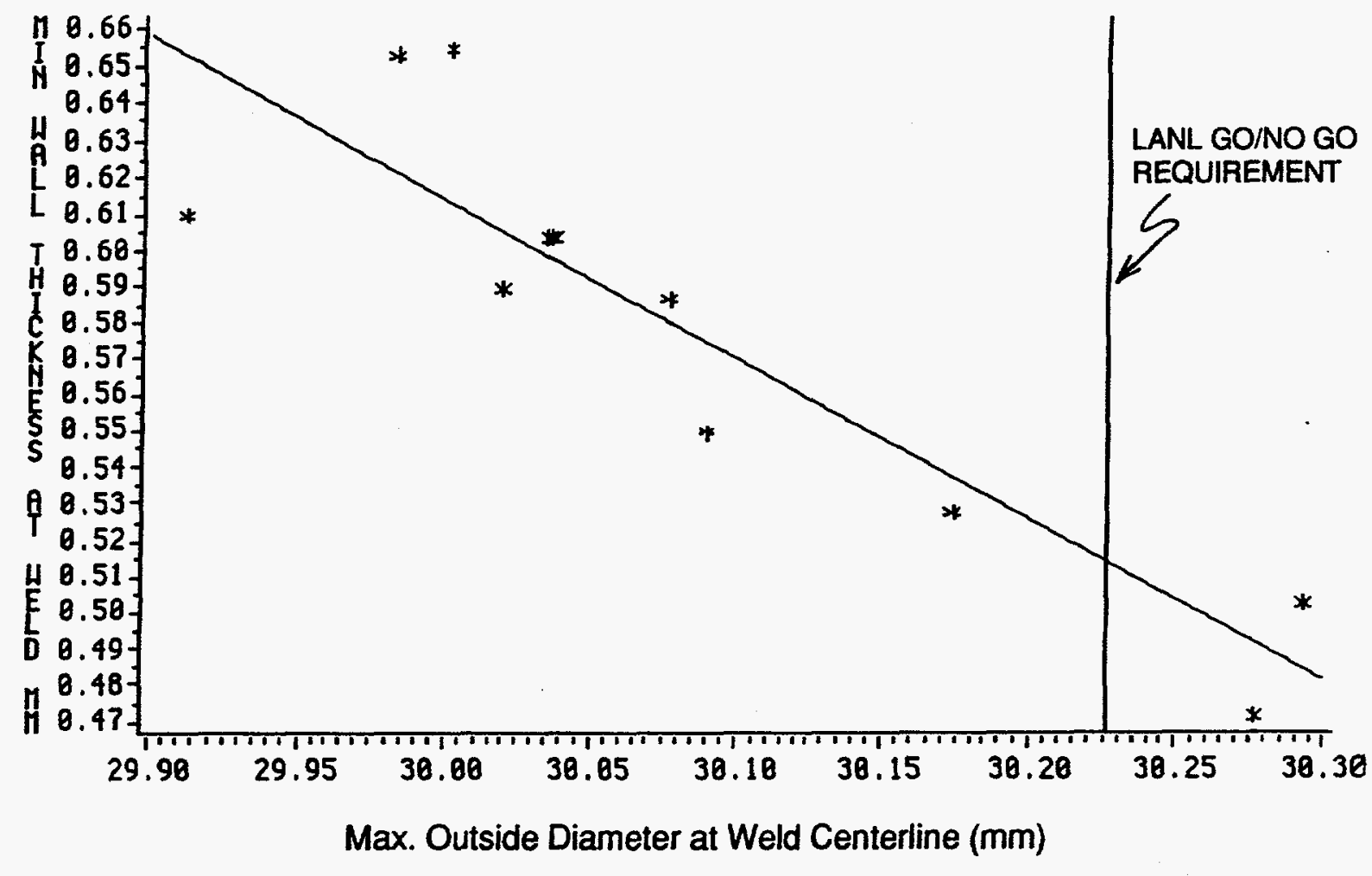

Regression Eq. Thickness $=13.823-0.440 \times$ Diameter, $R$ Value $=-0.090$

Fig. 2. Maximum diameter versus minimum wall thickness at weld centerline.

Figure 3 shows for 9 of the 11 CVSs that as the vent-notch area is increased up to $0.210 \mathrm{~mm}^{2}$, the greater the minimum wall thickness at the weld centerline, i.e., less wall thinning occurs. Note that the two CVSs with vent-notch areas of $0.254 \mathrm{~mm}^{2}$ and $0.256 \mathrm{~mm}^{2}$ were not included in Fig. 3 because significant thinning occurred, which may indicate that vent-notch areas near $0.250 \mathrm{~mm}^{2}$ are too large, i.e., there is too much material missing, to avoid excessive weld thinning. Nevertheless, the $r$ value for the data in Fig. 3 is +0.94. Again, coincidentally, the regression equation predicts that CVSs welded with a total vent-notch area near the minimum for one standard and one wide notch, $0.105 \mathrm{~mm}^{2}$, will have a minimum wall thickness at the weld centerline very close to the formed cup minimum wall thickness requirement of $0.55 \mathrm{~mm}$.

Data in Table 1 also show that as the total vent notch area is increased up to $0.210 \mathrm{~mm}^{2}$ the reduction between the wall thickness near the vent notches before welding and the minimum wall thickness at the weld centerline after welding decreases. These data have an $r$ value of -0.94 . The regression equation for these 9 pairs of data is as follows:

$$
\text { Wall thickness reduction }=0.220-1.039 \mathrm{x} \text { vent notch area. }
$$

All of the data listed in Table 1 and graphed in Figs. 2 and 3 show that the least bulging/thinning occurred with notch areas of $0.147 \mathrm{~mm}^{2}$ (corresponds approximately to the typical area for one standard notch mated to one wide notch) to $0.210 \mathrm{~mm}^{2}$ (corresponds to a vent-notch area slightly above the maximum area permitted for one standard notch mated with one wide notch). This 


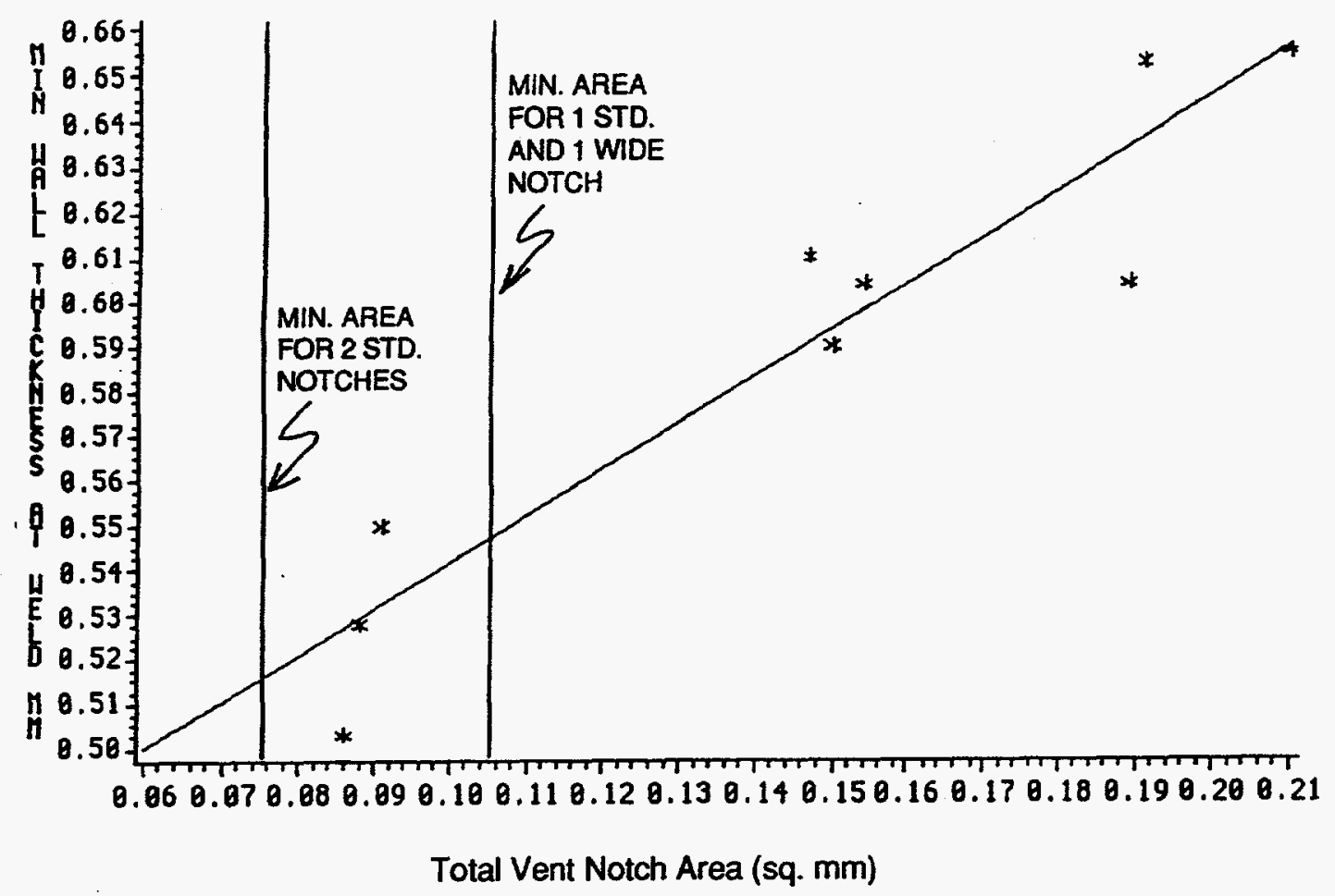

Regression Eq. Thickness $=0.438+1.039 \times$ Notch, $R$ value $=0.94$

Fig. 3. Total vent-notch area versus minimum wall thickness at weld centerline.

range of notch areas improves the consistency of the internal pressure release prior to weld fusion of the vent notches. Thus, bulging and concomitant thinning are minimized. Yet, the notch areas are not excessively large to produce thinning due to lack of metal available for welding. Based on these results, CVSs with vent-notch areas up to $0.210 \mathrm{~mm}^{2}$ are acceptable for flight-quality use.

Based on the successes of this study and the initial production welding (over ${ }^{238} \mathrm{PuO}_{2}$ pellets) at LANL of the 10 CVS units having wide shield-cup-vent notches, the CVS flight-quality design requirements were modified to permit shield-cup-vent-notch widths to range from 0.45 to $0.60 \mathrm{~mm}$, meaning that the total vent-notch area for flight-quality CVSs can range from 0.105 to $0.190 \mathrm{~mm}^{2}$. A total of $74{ }^{238} \mathrm{PuO}_{2}$-fueled CVSs with wide vent notches have been welded at LANL. Only 2 (2.7\%) of these units have been rejected for bulges/blowouts. This result is a dramatic four-fold improvement over either the $11.8 \%(27 / 229)$ bulge/blowout rejection rate for all fueled CVSs with standard vent notches in both cups or the $12.7 \%$ (21/165) rejection rate for fueled CVSs with standard vent notches in both cups that were welded since February 1995 through mid-August 1996 using a consistent peak current of $116 \mathrm{~A}$.

To simplify CVS manufacturing and thus reduce the potential for manufacturing errors, it would be desirable to have the same vent-notch dimensional requirements for both the vent and the shield cups. This goal could be achieved by modifying the vent-notch width and/or depth requirements. The preferred vent-notch dimensional requirements are $0.20 / 0.25 \mathrm{~mm}$ deep by $0.30 / 0.40 \mathrm{~mm}$ wide. The CVS vent-notch areas then could range from $0.120 \mathrm{~mm}^{2}$ to $0.200 \mathrm{~mm}^{2}$. These areas are slightly above the minimum and maximum areas of $0.105 \mathrm{~mm}^{2}$ to $0.190 \mathrm{~mm}^{2}$, respectively, for mating one standard notch and one wide notch. The data in Table 1 and Fig. 3 indicate that these slightly increased vent-notch areas will tend to reduce the extent of thinning at the weld centerline. Fig. 2 indicates that these vent-notch areas will translate to reduced bulging and thus possibly to a further improved yield for the closure-weld operation. As a precautionary measure, 
these preferred vent-notch dimensional requirements should be properly evaluated before changing the design requirements.

Consideration should also be given to altering the welding parameters ${ }^{1}$ to minimize further or to eliminate the potential for excessive bulging/thinning. The simplest approach would be to start (and complete) the weld taper earlier so that the heat input is lower once the vent notches are closed. For most of Cassini production, the weld taper began with the peak current of $116 \mathrm{~A}$ at the vent notches tapering down to $22 \mathrm{~A}$ at approximately $144^{\circ}$ past the vent notches. As was pointed out earlier, the maximum bulging/thinning occurs $20^{\circ}$ to $30^{\circ}$ beyond the vent notches. This fact indicates that too much heat input is occurring once the vent notches are fused closed. The internal pressure builds rapidly and bulges/thins the hottest (lowest strength and highest ductility) region. Most likely, the weld taper could begin approximately $10^{\circ}$ before the vent notch to permit most of the pressure to be relieved before closure of the notches, yet still producing complete fusion through the vent-notch region. 


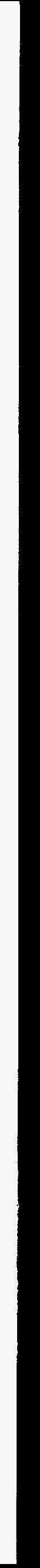




\section{CONCLUSIONS}

The results of this evaluation indicate that the extent of bulging and thinning is reduced without introducing other deleterious effects if the maximum total vent-notch area does not exceed $0.210 \mathrm{~mm}^{2}$. This limit is comfortably above the maximum total vent-notch area of $0.190 \mathrm{~mm}^{2}$ permitted by the iridium cup drawing M2D920101A005, Rev. B, which allows for a widened shield cup vent notch $(0.45 / 0.60 \mathrm{~mm}$ wide by $0.15 / 0.20 \mathrm{~mm}$ deep) to be mated with a vent-cup assembly with a standard vent notch $(0.25 / 0.35 \mathrm{~mm}$ wide by $0.15 / 0.20 \mathrm{~mm}$ deep $)$. Therefore, CVSs with ventnotch areas of up to $0.210 \mathrm{~mm}^{2}$ are acceptable for flight-quality use.

The LANL production results for welding flight-quality CVSs with a widened shield cup vent notch over ${ }^{238} \mathrm{PuO}_{2}$ fuel pellets show a four-fold improvement in the bulge/blowout rejection rate from that for CVSs with only standard vent notches.

For manufacturing simplicity, the vent-notch dimensional requirements for the vent and the shield cups should be the same: $0.20 / 0.25 \mathrm{~mm}$ deep by $0.30 / 0.40 \mathrm{~mm}$ wide. This requirement will allow the CVS vent-notch areas to range from $0.120 \mathrm{~mm}^{2}$ to $0.200 \mathrm{~mm}^{2}$. Maintaining the CVS ventnotch areas in this range is expected to reduce the potential for bulges and blowouts and thus possibly to improve further the yield of the closure-weld operation. Of course, any proposed design change, no matter how minor it is thought to be, must be properly evaluated before it is accepted.

The weld-taper parameters, primarily time/location of taper start, should be evaluated for their effects on bulging/thinning. 



\section{FUTURE WORK}

The extremes of the proposed vent-notch dimensions should be evaluated in a manner similar to the work just presented. A weld-taper parameter evaluation should include one set of CVSs welded with the taper beginning $0.2 \mathrm{~s}$ or $\sim 10^{\circ}$ earlier. Additional evaluations should be done in $0.1-\mathrm{s}$ or $\sim 5^{\circ}$ increments. Also, to understand better the venting process, excessively deep notches (extending beyond the weld zone so that the deepest parts of the notches are not fused) could be ground into some cups before welding. After being welded, these CVSs should have very little or no bulging/thinning. 



\section{ACKNOWLEDGMENTS}

The author thanks the following personnel for their contributions to this study: the Building 9201-1 Can Shop and Inspection personnel for grinding and inspecting the 24 cups and vent notches; M. W. Moyer and T. W. Dews for ultrasonic inspection; J. F. King, R. W. Reed, and E. A. FrancoFerreira for the closure welds; the Building 2547 Inspection personnel for the inspections at the weld centerlines; and T. G. George and E. M. Foltyn for supplying the LANL production data. 



\section{REFERENCE}

1. E. A. Franco-Ferreira and T. G. George, "Cassini Mission to Saturn Relies on Flaw-Free GTA Welds," Welding Journal, April 1996. 
Distribution

\section{Department of Energy - Oak Ridge Operations}

S. R. Martin, Jr.

Department of Energy - Office of Engineering and Technology Development

W. J. Barnett

B. A. Cook

S. M. Franks

R. R. Furlong

A. S. Mehner

R. C. Raczynski

E. J. Wahlquist

EG\&G-MAT, Inc.

D. M. Gabriel

E. I. Howell

F. A. Koehler

J. R. McDougal

D. C. McNeil

\section{Lamb Associates}

E. W. Johnson

\section{Los Alamos National Laboratory}

E. M. Foltyn

T. G. George

Oak Ridge National Laboratory

R. H. Cooper

E. A. Franco-Ferreira

J. F. King

G. V. Luttrell

E. K. Ohriner

J. P. Moore

R. W. Reed

Oak Ridge Y-12 Plant

T. A. Arehart, Jr.

H. W. Berry

T. W. Dews

J. E. Greer 
K. J. Helle

S. G. Jessing

A. K. Lee/DOE-OSTI (2)

M. W. Moyer

T. M. Mustaleski, Jr.

W. G. Northcutt/E. L. Bird

G. B. Ulrich (3)

A. T. Woods

R. C. Wright

Y-12 Central Files - RC 